371.3::811.163.41

811.163.41'367.625

https://doi.org/10.18485/kij.2018.65.3_4.10

ТАНА Ж. ИЛИЪ *

Економско-трговинска школа

Пожаревац
Оригинални научни рад

Примљен: 12. 10. 2018.

Прихваћен: 15. 11. 2018.

\title{
О ГЛАГОЛСКОЈ РЕКЦИЈИ У ПИСМЕНИМ ЗАДАЦИМА ПОЖАРЕВАЧКИХ УЧЕНИКА
}

\begin{abstract}
Писмено изражавање ученика показатељ је њиховог стилског, али и језичког умећа. У раду се анализирају примери употребе нестандардне глаголске рекције у писменим задацима ученика првог разреда средње стручне школе из Пожаревца (с говорног подручја косовско-ресавског дијалекта), тј. глаголске рекције која није у складу са српским стандардним језиком. Анализиран је и упитник у ком су истим ученицима дати примери у реченичном контексту слични оним из писмених задатака. Циљ је осветљавање фактора који утичу на појаву нестандардних облика, при чему се издвајају два доминантна типа алтернирања (смењивања) рекцијских облика - дативно-локативне и инструменталне, односно акузативне и инструменталне рекције.
\end{abstract}

Кључне речи: рекцијски облик, рекцијска допуна, глаголска рекција, алтернирања рекцијских облика, писмени задаци, косовско-ресавски дијалекат, српски стандардни језик.

\section{1. Увод}

\section{1. Уводне напомене}

Писмени задаци огледало су стилског и језичког умећа ученика. За потребе овог рада анализирали смо употребу нестандардних рекцијских облика у писменом изражавању ученика, тј. рекцијских допуна које нису у складу са српским стандардним језиком. Циљ нам је, стога, анализа фактора који утичу на њихову појаву.

Грађа је ексцерпирана из писмених задатака ученика првог разреда Економско-трговинске школе из Пожаревца. Реч је о одељењима средње стручне школе, и то о одељењима трећег степена (смерови - трговац, кувар, конобар) и четвртог

*tanja.ilic.90@gmail.com 
(смер - трговински техничар). Ученици су из Пожаревца и околних села, дакле, говорници су косовско-ресавског дијалекта, који није у основици српског стандардног језика. Задаци су рађени током школске 2017/2018. године.

\section{2. Појам рекције}

„Појава да нека реч тражи као допуну именичку јединицу у одређеном зависном падежу или предлошко-падежној конструкцији назива се рекција" (Станојчић / Поповић 2014: 245). У вези с глаголима оперише се терминима рекцијски глаголи (допуњавају се објектом), рекиијска допуна глагола (објекат), рекцијски облик (допуна у одређеном зависном падежу) и рекиијска конструкиија (спој рекцијског глагола и објекта) (Станојчић / Поповић 2014: 245). Облик зависне речи притом зависи од управне речи, њеног лексичког и творбеног значења, као и од припадности одређеној врсти речи, а може зависити и од значења зависне речи. Од значаја је и устаљеност рекције неке речи током језичког развоја (Пипер / Клајн 2013: 276), као и обележје аниматности и рекцијско окружење (Ружић 2012: 105). Такође, до промене рекције речи може доћи услед језичког развоја $^{1}$ (Ружић 2012: 104).

\section{3. О рекцији у литератури}

Иако је тешко прописати критерије за употребу рекцијских облика, будући да многе речи српског језика „имају веома сложену и развијену полисемантичку структуру, а самим тим и широку колокабилност и морфосинтаксичку спојивост" (Ружић 2012: 104), граматике српског језика пружају преглед глагола ${ }^{2}$ одговарајућом рекцијском допуном (Пипер / Клајн 2013: 276-278; Станојчић / Поповић 2014: 247, 288-289, где се наводи и рекција именица и придева). Cpnски језички приручник такође разматра примере нестандардне рекције појединих глагола (нпр. оженити, оченити, контактирати, председавати итд.) (Ивић и др. 2011: 145-147), као и Синтакса савременога српског језика, која пружа табеларни преглед глаголске, именичке, придевске рекције и упоредну рекцију глагола, именица и придева (Ружић 2005: 542-547). Граматика за средњу стручну школу (и гимназију) која је у употреби у првом разреду, рекцију не обрађује, будући да морфологија као наставна тема није ни предвиђена наставним планом у првој години (Ломпар 2012), већ у другој³ (Ломпар / Антић 2014). Тек се у гра-

${ }^{1} \mathrm{O}$ језичким иновацијама у омладинском жаргону на плану глаголског рода, те глаголске рекције в. Крцић 2018.

${ }^{2}$ Глаголска рекција се као „најразуђенија” доследније представља у речницима од именичке и придевске (Ружић 2005: 547).

${ }^{3}$ У другој години средње школе планирано је у настави језика стицање знања о морфологији у ужем смислу и променљивим и непроменљивим врстама речи, те тако и о глаголима и граматичким категоријама глагола, али без помена о рекцији. Само се у „питању са маргине”, иначе предвиђеним да ученике упути на везу с другим областима граматике, поставља питање: „Знаш ли у ком значењу непрелазни глаголи помоћи и помагати (некоме) могу постати прелазни и имати прави објекат?" (Ломпар / Антић 2014: 121). Одговор је дат на крају књиге (Ломпар / Антић 2014: 216). 
матици за трећу годину, у склопу учења о синтакси, о објекту говори као о „рекцијској (падежној) допуни глагола”. Дат је кратак списак глагола чији се рекцијски облици нестандардно употребљавају, тј. допуњавају именицом или заменицом у погрешном падежу, и напоменуто је да је понекад правилно допунити глагол именицом или заменицом у два облика (Ломпар / Антић 2015: 124). ${ }^{4}$

Ради бележења и провере стандардних рекцијских облика служили смо се описним једнотомним Речником српског језика Матице српске (РСЈ) и кратким рекцијским Речником глагола са допунама (Петровић / Дудић 1989), мада ови речници не бележе све рекцијске допуне глагола из наше грађе. Из тог разлога смо у појединим случајевима наводили облик за који постоји потврда (с разликом у глаголском виду и сл.) или смо се ослањали на сопствено језичко осећање.

Речник српскога језика глаголску рекцију обележава на неколико начина: 1. експлицитно, навођењем одговарајуће рекцијске допуне (заменичких облика у зависним падежима), 2. у склопу дефиниције, 3. посредно, путем примера употребе наведених после дефиниције. ${ }^{5}$ На то да се на овај начин могу добити обавештења о глаголској рекцији, упућује и уредник и редактор речника Мирослав Николић у тексту Из предговора претходном издану (РСJ: 9).

\section{2. Нестандардна употреба рекцијских допуна}

Наша грађа пружа примере алтернирања (смењивања) рекцијских облика. Издвојили смо само примере који се тичу глаголске рекције. ${ }^{6}$

\section{1. Алтернирање генитивне и дативно-локативне рекције}

2.1.1. о + локатив ум. код + генитив: „И то је ствар која ми се највише свића $^{7}$ o юему". О учесталој употреби предлога $o$ у савременом језику в. Ивић и др. 2011: 158.

2.1.2. преко + генитив ум. по + локатив: ${ }^{8}$ „да суде преко физичког изгледа, већ по ономе што се крије унутра". Као што видимо, у другом делу реченице допуна је исправно употребљена (,по ономе”).

\footnotetext{
${ }^{4}$ У истој граматици се још помињу и прилошке допуне глагола (Ломпар / Антић 2015: 126).

${ }^{5}$ На сличан начин се о рекцији могу добити обавештења у Речнику српскохрватског књижевног и народног језика САНУ (уп. нпр. рекцијске допуне глагола бринути, РСАНУ: 175) и у Петровић / Дудић 1989. В. и предговор аутора на стр. 5-10.

${ }^{6}$ Нормативна граматика српског језика према врсти речи којој припада управна реч у рекцијском односу рекцију дели на глаголску, именичку, придевску и прилошку, а према падежном облику зависног дела на генитивну, дативно-локативну, акузативну и инструменталну рекцију (Пипер / Клајн 2013: 277-278). За потребе овог рада служићемо се истим терминима.

${ }^{7}$ У циљу прегледности, у рекцијским конструкцијама подвукли смо глаголске облике, док смо курзивом истакли њихове рекцијске облике, онакве какве смо забележили у писменим задацима.

${ }^{8}$ PCJ допушта и употребу допуне на основу нечега, али везује је за разговорни језик (в. РСЈ: 1261). У Речнику глагола са допунама наведене су само допуне некоме/некога/нешто (Петровић / Дудић 1989: 108).
} 


\section{2. Алтернирање генитивне и инструменталне рекције}

2.2.1. генитив ум. беспредлошког инструментала: „њој се очи напуниле суза”, „Антигона је била испуњена сестринске љубави”. Уп. напунити = 1.а. учинити пуним, попунити, испунити нечим (РСЈ: 772, курзив - Т. И.). Претпостављамо да је узрок нестандардне рекције аналогија према конструкцији бити пун нечега.

\section{3. Алтернирање дативно-локативне и инструменталне рекције}

2.3.1. беспредлошки датив ум. беспредлошког инструментала: „Ја сам одушевљен окружеюу моје нове школе";

2.3.2. беспредлошки инструментал ум. беспредлошког датива: ${ }^{9}$ „Имам два узора која гледам да ме науче нечим"; 10

2.3.3. беспредлошки инструментал ум. $y+$ локатив: ,jе кренула да подучава $^{11}$ децу тим спортом";

2.3.4. са + инструментал ум. y/по+ локатив: „варају се са юиховим мишљењима", ${ }^{12}$,у животу имам два циља - да успем са школом као и са сnортом”, „Распознавају се ${ }^{13}$ једино са својим манама, предностима и изгледом”;

2.3.5. по + локатив ум. беспредлошког инструментала: „Људи те инспиришу по томе што раде". ${ }^{4}$

Како примећујемо, алтернирају датив и инструментал у беспредлошкој употреби и у већем броју примера инструментал и локатив и у предлошкој и у беспредлошкој употреби. И то се у свим примерима, с изузетком једног, инструменталом замењује локатив.

\footnotetext{
${ }^{9}$ У значењу подучити кога чему глаголу научити одговарају допуне некога нешто/нечему/да + презент (Петровић / Дудић 1989: 56).

${ }^{10}$ Ум. допуне овог глагола у беспредлошком дативу забележили смо у грађи и допуну $о+л о-$ катив: „Научи свој тип о нечему новом или га форсира”, „која ме је научила о култури, понашағу и о томе". Претпостављамо да је ту узрок нестандардне глаголске рекције аналогија према глаголу учити (услед обличке и семантичке сличности), коме наведен рекцијски облик одговара (уп. учити о некоме/нечему). Додуше, РСЈ не наводи ову допуну глагола учити, већ само учити некога/нешто, тј. учити се нечему (РСЈ: 1397, в. и Петровић / Дудић 1989: 119).

${ }^{11}$ РС бележи рекцијски облик за свршени видски лик: подучити = пренети некоме знање, вештину у певању (РСJ: 940). Сматрамо да је уз глагол подучавати, поред допуне у беспредлошком акузативу, могуће употребити и допуну у беспредлошком дативу (подучавати некога нечему).

${ }^{12}$ Потврду за рекцијску допуну у + локатив уз глагол варати се налазимо у Петровић / Дудић 1989: 16

${ }^{13}$ РС бележи само допуну у беспредлошком акузативу, и то за свршени видски лик-распознати некога (РСJ: 1113).

14 Замена локатива инструменталом, до које долази у неким говорима косовско-ресавског дијалекта, јавља се у синтагматској форми и при употреби месних предлога (в. Радић 1997: 231).
} 


\section{4. Алтернирање акузативне и генитивне рекције}

2.4.1. беспредлошки акузатив ум. беспредлошког генитива: ${ }^{15}$ „Сваки секунд, сваки минут радо се сећам". О томе да временски генитив не треба замењивати акузативом ${ }^{16}$ у стандардном језику в. Пипер / Клајн 2013: 333.

2.4.2. на + акузатив ум. беспредлошког генитива: „Када имаш неког на ког можеш да се ослониш и на кога ћеш да се увек сетиш”. Глагол сетити се допуњен је истим рекцијским обликом какав одговара глаголу ослонити се, који му у истој реченици претходи.

2.4.3. на + акузатив ум. изнад + генитив: „али на сваки пад сам се уздигла” (в. РCJ: 1352).

У свим примерима је акузативна рекција нестандардно употребљена уместо генитивне. Дијалектолошка литература продор облика акузатива као општег падежа уместо генитива (и инструментала и локатива) у говорима косовско-ресавског дијалекта објашњава тежњом ка аналитизму (Ивић 2009: 65-66).

\section{5. Алтернирање акузативне и дативно-локативне рекције}

2.5.1. беспредлошки акузатив ум. о/у + локатив: „Изабрала сам да пишем сестру Милииу”, „Много опширније пише живот господина Симеона” (Претпостављамо да је до употребе нестандардне глаголске рекције дошло аналошки према глаголу описивати, коме употребљена рекција, те прави објекат, одговара - уп. описивати некога/нешто. ), „кућа коју сам маштала”, „Моје активности које ја уживам"; 17

2.5.2. за + акузатив ум. $о$ + локатив: „И много је бринуо за мене”. (= Старао се о мени.)

Рекцијски облик глагола бринути може имати семантички диференцијалну улогу, уп. бринути за неког (= бити забринут, страховати) : бринути некога (= забрињавати некога) : бринути о некоме (= водити рачуна / старати се о некоме) (РСЈ: 107, в. и Петровић / Дудић 1989: 15-16, Радић 2003: 132-133); ${ }^{18}$

${ }^{15}$ Потврду за рекцијску допуну уз глагол сећати се у беспредлошком генитиву налазимо у Петровић / Дудић 1989: 102.

${ }^{16}$ Верујемо да у граматици на коју се позивамо, грешком на овом месту пише номинатив, будући да у ијекавском издању, измењеном и допуњеном према екавском, стоји акузатив (Пипер / Клајн 2015: 339).

${ }_{17}$ У значењу осећати задовољство овај глагол је непрелазни и одговара му допуна $y+$ локатив (Петровић / Дудић 1989: 113).

${ }^{18}$ Различита значења траже различиту рекцију. Уп. нпр. беспредлошки датив : беспредлошки акузатив - помоћи/помагати некоме (= олакшати вршење неког рада, дати помоћ, потпору у нечему $\sim$ копању, писању, РСЈ: 956) : помоћи/помагати некога (= пружити некоме материјалну помоћ, Ломпар / Антић 2014: 216); служити некоме/нечему (= радити у нечију корист отаџбини, непријатељу, PCJ: 1219) : служити некога (= доносити и давати јело и пиће, послуживати госте, вечеру, РСJ: 1219). Конструкције с напоредном употребом рекцијских допуна овог типа стилски су ефектне. Један од рекламних слогана за пиће „швепс” („Schweppes”) нпр. гласи - „За оне који шетају с тобом, а не тебе" (истицање - Т. И.). 


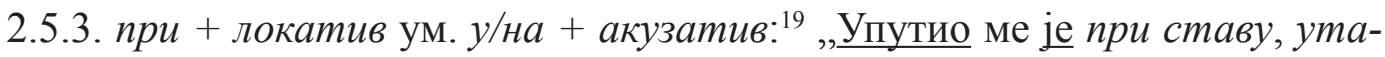
кмици, играчу”.

У наведеним примерима, сем у једном, акузативна рекција употребљена је нестандардно уместо дативно-локативне, те искључиво облика локатива. Ово стање се опет може довести у везу с морфосинтаксичким особеностима косовско-ресавског дијалекта, будући да „Lokativ se često zamjenjuje oblikom opšteg padeža na cijelom govornom području”, који је „u govore kosovsko-resavskog dijalekta prodro pod uticajem balkaniziranih susjednih govora” (Окука 2008: 206).

\section{6. Алтернирање акузативне и инструменталне рекције}

2.6.1. беспредлошки акузатив ум. с (a) + инструментал: „Рукомет сам почела због другарица", „престао сам дружене са њима". У питању су фазне конструкције, ${ }^{20}$ којима одговара инструментална рекција (Станојчић / Поповић 2014: 247).

2.6.2. као + акузатив ум. беспредлошког инструментала: „Мене моји другари сматрају као особу на коју могу да се ослоне”, „Ја себе сматрам као некако надарену особу". У овој конструкцији с допунским предикатом треба употребити или инструментал или конструкцију за + акузатив ${ }^{21}$ (Ивић и др. 2011: 146, Пипер / Клајн 2013: 278, Станојчић / Поповић 2014: 251).

2.6.3. на + акузатив ум. беспредлошког инструментала: „да вам показују на какве погрешне путеве су они ишли".

2.6.4. на + акузатив ум. с(а) + инструментал: „да настави на тај посао”.

2.6.5. с (a) + инструментал ум. беспредлошког акузатива: „Отишли смо да шетамо са керовима". Уп. шетати: 2.а. изводити некога у шетњу дете, пса (PCJ: 1504).

У свим примерима, сем у једном, акузативна рекција употребљена је нестандардно уместо инструменталне. И овде (као и у 2.5), можемо закључити да акузатив има облик општег падежа, који сем локатива замењује и инструментал, а спорадично и друге падеже (Окука 2008: 206), нпр., како смо видели, генитив (в. 2.4).

Како „У већини говора [косовско-ресавског дијалекта - прим. Т. И.] нестаје разлика између акузатива као падежа правца и локатива и инструментала као падежа места" (Ивић 1994: 224), међусобна алтернирања дативно-локативне, акузативне и инструменталне рекције су очекивана.

\footnotetext{
${ }^{19}$ Ова допуна уз глагол упућивати се, у значењу упознати се с чиме, научити што, забележена је у Петровић / Дудић 1989: 118.

${ }^{20}$ У овим конструкцијама могуће је употребити и сложени предикат састављен од фазног и допунског дела предиката (инфинитив/да + презент).

${ }^{21}$ Допушта се употреба као уз глагол сматрати се кад је он узајамно-повратни (Петровић / Дудић 1989: 104).
} 


\section{3. Из анализе једног упитника за ученике}

Желећи да испитамо владање рекцијом у реченичном контексту, ученицима одељења I разреда кувара и трговинских техничара, чије смо задатке анализирали, дали смо упитник, где смо настојали да употребимо сличне примере из њихових писмених задатака.

Дата су им усмена објашњења пре почетка рада и отклоњене значењске недоумице у примерима за које су ученици тражили појашњење. Четрдесет троје ученика је попуњавало следећи упитник:

> Допуни следеће реченице тако што ћеш реч у загради ставити у одговарајући падежни облик, тј. предлошко-падежну конструкцију.

Нпр. Размишљам о лету

1. Подучава децу

$$
\text { . (лето) }
$$

$$
\text { . (спорт) }
$$

2. Одушевљен сам (окружење)

3. Инспирисан

4. Имам вољу

$$
\text { . (природа) }
$$

$$
\text { . (учење) }
$$

5. Поносан . (друг) (= Друг је разлог за понос. $)^{22}$

6. Осећам дивљење . (ти) $(=$ Ти си разлог за дивљене.)

7. Упућен Добро обавештен о спортским дешавањима.)

8. Bapajy ce (своје мишљење)

9. Одушевила ме (поклон који је купила)

10. Добио сам инспирацију нем да сликам)

11. Људи те инспиришу

12. Поносим се . (поступци)

13. Дивим се . (друг) . (ти)

${ }^{22}$ Реченице у загради обележене курзивом ученицима су дате ради појашњења реченичног контекста. 
Ученици који су погрешно одговорили навели су следеће рекцијске облике:

1. о спорту 25 , спортом 13, сnорm 1 , спорта 1 , сnорту 1

2. о окружењу 2, са окружењем 2, окружењу 1, због окружења 1

3. о природи 1

4. за учењем $21,{ }^{23}$ о учењу 1

5. рууг(ар) 9, другом 6, о другу 1

6. теби 6, о теби 3, ти 3, тебе 2, за тобом 2, тобом 1, у теби 1 (Један ученик је навео као исправна оба облика - теби/тобом.)

7. спортским дешавањима 7 (спортским дешавањем 2), о спортским дешавањима 4 (о спорту 1), спортском дешавану 2, за спортска дешавањьа 1

8. својим мишьеюем 20 (својим мишьењима 2), за своје мишљење 4, своја мишљењь 3, своје мишљење 1, са својим мишљењем 1, око свог мишьења 1, својим мислима 1

9. са поклоном 2, поклоном којим ми је купила 2 (Уочавамо хиперкоректну употребу инструментала; подвлачење - Т. И.), због поклона 1 , поклоне 1

10. за сликањем 11, сликањем 3, сликања 2, о сликању 2

11. о поступциима 2 , за поступке 1 , са својим поступщима 1

12. свом другу 1, с другом 1

13. тобом 7

На основу добијених најфреквентнијих одговора можемо извести следеће појединачне закључке:

- Дативно-локативна рекција замењена је инструменталном $\left(1,{ }^{24} 8,13\right.$. реченица), као и инструментална дативно-локативном рекцијом $(2,3$, 11, 12. реченица).

- Акузативна рекција замењена је инструменталном $(4,5,7,10$. реченица).

- $\quad$ У инструменталној рекцији уочава се хиперкоректна употреба предлога $c($ a) $(2,8,9,11,12$. реченица).

- Међу узроцима нестандардне рекције су семантичка диференцијација (10. реченица $)^{25}$ и упоредна рекција $(5,6$. реченица). Упоредна рекција тиче се употребе различите рекције глагола, именица и придева „од исте основе или од семантички блиских глаголских, именичких и придевских лексема”26 (Ружић 2005: 547). При избору реченица намерно

${ }^{23} \mathrm{O}$ ширењу конструкције $з а+$ инструментал науштрб конструкције $з а+$ акузатив в. Ивић и др. 2011: 141. Интересантно је да је конструкција за + инструментал ум. за + акузатив такође употребљена и у 10. реченици, али је више ученика погрешило у 4. Дакле, колебања у употреби чешћа су у вези с појединим лексичким облицима.

${ }^{24} \mathrm{У}$ вези с првом реченицом најфреквентнији одговор је рекцијски облик $o+$ локатив (ум. допуне $y+$ локатив, односно у беспредлошком дативу). Тенденцију појачане употребе ове рекцијске допуне, те предлога $о$, уочили смо и у другим примерима (уп. одговоре у реченицама $1,2,3,6,7,11$ ).

${ }^{25}$ Ученици су разумели да је инспирација добијена захваљујући сликању.

${ }^{26}$ Уп. и нпр. примере дивити се некоме/нечему (глагол + рекција) : дивљење према некоме/нечемy (именица + рекција) : задивљен неким/нечим (придев + рекција); инспирисати (некога) нечим/на 
смо се зато одлучили за својеврсне „паралелизме” (оличене у реченицама 2 и 9, 3, 10 и 11, 5 и 12, 6 и 13) - семантички и облички сличне управне речи које траже различиту рекцијску допуну. Претпоставили смо да ће семантичка и обличка сличност утицати на то да се ученици у њима одлуче за исте рекцијске облике, што се и потврдило у 5 . и 6. реченици.

\section{4. Закључак}

Анализирали смо примере употребе рекцијских облика ексцерпираних из писмених задатака ученика првог разреда средње стручне школе из Пожаревца, и то одељења трећег и четвртог степена. Очекивано, више погрешака нашло се међу ученицима одељења трећег степена, чијих је радова сразмерно више у нашој грађи, а који важе за слабије ђаке у односу на ученике одељења четвртог степена, што обично потврђује успех с којим су завршили основношколско образовање. Такође их је више из сеоских (дијалекатских) средина.

Употребу нестандардних рекцијских облика у писменом изражавању ученика можемо тумачити специфичностима дијалекта, те тако резултатом недовољног усвајања стандарднојезичке норме, али и недовољно развијеним језичким осећањем. Исто је показао и упитник са сличним примерима из писмених задатака, где су се ученици одлучивали за „исправне” рекцијске облике у реченичном контексту.

У писменим задацима уочили смо алтернирања следећих рекцијских облика: генитивне и дативно-локативне, генитивне и инструменталне, дативно-локативне и инструменталне, акузативне и генитивне, акузативне и дативно-локативне и акузативне и инструменталне рекције. Међу њима највише је примера за алтернирање:

- дативно-локативне и инструменталне рекције,

- $\quad$ акузативне и инструменталне рекције, где је у свим примерима, сем у једном, акузативна рекција нестандардно употребљена уместо инструменталне.

И при алтернирању акузативне и дативно-локативне рекције у свим примерима, с изузетком једног, акузативна рекција употребљена је нестандардно уместо дативно-локативне, а доследно уместо генитивне рекције. Акузатив, дакле, у облику општег падежа има широк домен употребе, што је једна од морфосинтаксичких одлика косовско-ресавског дијалекта.

Анализа упитника показала је сличну ситуацију, те се и у упитнику алтернирање дативно-локативне и инструменталне рекције показало најзаступљенијим, као и алтернирање акузативне и инструменталне рекције, с том разликом у од-

нешто (глагол + рекција) : инспирација за нешто (именица + рекција) : инспирисан неким/нечим/за нешто (придев + рекција) и сл. 
носу на грађу из писмених задатака да је у свим примерима акузативна рекција замењена инструменталном.

Инструменталној рекцији својствено је уопштавање предлога $c(a)$, а дативно-локативној уопштавање предлога $o$.

Проблем нестандардне рекције уочен је и описан у литератури (језичким приручницима, граматикама), али само за поједине глаголе код којих, сматрају аутори, чешће долази до грешака. Уз то, рекцијских речника има јако мало и тешко су доступни, а ни они, као ни наши описни речници, не бележе све рекцијске допуне. Треба имати у виду и то да услед језичког развоја може доћи до промене рекције речи, због чега се и стање у речницима мора актуелизовати.

Свакако да би опсег глагола (и именица и придева) чијим би исправним рекцијским облицима требало посветити пажњу, морао бити шири, уз уважавање реченичног контекста и језичке стварности с њеним семантичким нијансама. У раду би ученике ваљало подстаћи да уоче да различита значења захтевају различиту рекцију, нпр. бринути за некога/о некоме, служити некоме/некога. Такође, неопходно је обратити пажњу и на упоредну рекцију, нпр. дивити се некоме : дивљење према некоме. У вези с тим било би корисно истражити колико се пажње упоредној рекцији (и рекцији уопште) поклања при учењу српског језика као страног, где може бити важан сегмент разумевања уистину компликованих односа у које ступају речи у реченици унутар језичког система српског језика.

Ученицима, такође, нарочито треба скретати пажњу на то да аналогија према облички и семантички сличним примерима може често бити узрок замене рекције. Нпр. допуна $о$ + локатив нестандардно се употребљава уз глагол научити аналогијом према глаголу учити, коме пак одговара.

Свесни смо да је корпус за спроведено истраживање мали, те и за утврђивање правилности употребе појединих нестандардних модела. Примарни циљ нам је стога био указивање на фреквентност грешака у писменом изражавању, на разлоге њихове појаве, а тиме и на важност теме рекције, за коју би се у настави језика морало наћи знатно више места.

\section{ЛИТЕРАТУРА}

Ивић 1994: Павле Ивић, Српскохрватски дијалекти: њихова структура и развој, Сремски Карловци - Нови Сад: Издавачка књижарница Зорана Стојановића.

Ивић 2009: Павле Ивић, Српски дијалекти и ґихова класификација (приредио Слободан Реметић), Сремски Карловци - Нови Сад: Издавачка књижарница Зорана Стојановића.

Ивић и др. ${ }^{52011}$ : Павле Ивић, Иван Клајн, Митар Пешикан, Бранислав Брборић, Српски језички приручник, Београд: Београдска књига. 
Крцић 2018: Ненад Крцић, „Граматичке и семантичке измене глагола у језику младих", Свет речи, 45-46, Београд: Друштво за српски језик и књижевност Србије, 47-50.

Ломпар 2012: Весна Ломпар, Граматика: српски језик и књижевност за први разред гимназија и средњих стручних школа, Београд: Klett.

Ломпар / Антић 2014: Весна Ломпар, Александра Антић, Граматика: српски језик и књижевност за други разред гимназија и средњих стручних школа, Београд: Klett.

Ломпар / Антић 2015: Весна Ломпар, Александра Антић, Граматика: сpnски језик и књижевност за трећи разред гимназија и средњих стручних школа, Београд: Klett.

Окука 2008: Miloš Okuka, Srpski dijalekti, Zagreb: Prosvjeta.

Петровић / Дудић 1989: Владислава Петровић (Ружић), Коста Дудић, Речник глагола са допунама, Београд - Нови Сад - Сарајево: Завод за уџбенике и наставна средства - Завод за издавање уџбеника - Свјетлост.

Пипер / Клајн 2013: Предраг Пипер, Иван Клајн, Нормативна граматика српског језика, Нови Сад: Матица српска.

Пипер / Клајн 2015: Предраг Пипер, Иван Клајн, Нормативна граматика српског језика - Ијекавско изд., измијењено и допуњено (према другом екавском изд.), Нови Сад: Матица српска.

Радић 1997: Првослав Радић, „О неким појавама у деклинацији косовско-ресавских говора (у светлу синкретичко-аналитичких процеса)", у: Зборник Матице српске за филологију и лингвистику, XL/2, Нови Сад, 227-240.

Радић 2003: Првослав Радић, „О два аспекта балканизације српског књижевног језика", у: Јужнословенски филолог, LIX, Београд, 105-152.

РСАНУ: Речник српскохрватског књижевног и народног језика, књ. II, Београд: Српска академија наука и уметности, 1962.

PCJ: Речник српскога језика, Нови Сад: Матица српска, 2011.

Ружић 2005: Владислава Ружић, Рекцијски односи у глаголској, именичкој и придевској синтагми, у: Синтакса савременога српског језика: Проста реченица (Предраг Пипер и др.; у редакцији Милке Ивић), Београд - Нови Сад: Институт за српски језик САНУ - Матица српска, 536-548.

Ружић 2012: Владислава Ружић, „Рекција и норма”, Научни састанак слависта у Вукове дане, 41/1, Београд, 103-112.

Станојчић / Поповић 2014: Живојин Станојчић, Љубомир Поповић, Граматика српског језика за гимназије и средње школе, Београд: Завод за уџбенике. 
Tanja Ž. Ilić

\title{
OF VERB DEPENDENCY IN WRITTEN TESTS DONE BY STUDENTS FROM POŽAREVAC
}

\author{
Summary
}

Written expression of students is an indicator of their stylistic and linguistic skill. Through work, we analyze examples of non-standard verb dependency usage in written tests done by freshmen of Secondary vocational school in Požarevac (from the speaking area of KosovoResavian dialect), i.e. verb dependency which is not in accordance with the Serbian standard language. We also analyzed a questionnaire given to these students, with examples in sentence context similar to those from the written tests. The goal is to lighten the factors which influence the occurrence of non-standard forms, whereby two dominant types of alternating (shifting) stand out - dative-locative, i.e. accusative and instrumental dependencies.

Key words: dependency form, dependency complement, verb dependency, alternating of dependency forms, written tests, Kosovo-Resavian dialect, Serbian standard language. 